\title{
REVIEW
}

\section{Lymphocytic choriomeningitis virus: ways to establish and maintain non-cytolytic persistent infection}

\author{
M. LABUDOVÁ, J. PASTOREK, S. PASTOREKOVÁ
}

Institute of Virology, Biomedical Research Center, Slovak Academy of Sciences, Dúbravská cesta 9, 84505 Bratislava, Slovak Republic

\begin{abstract}
Summary. - Lymphocytic choriomeningitis virus (LCMV) is a prototype virus of the Arenaviridae family that is attracting considerable attention both as an important experimental model system to study acute and persistent viral infections, and as a neglected human pathogen of clinical significance. Notably, LCMV is capable of persisting in an infected host, and escaping the immune system. Here we describe the strategies used by the virus to establish and maintain long-term infection in vitro and/or persistent infection in vivo. We discuss how the viral components (RNA, nucleoprotein, glycoprotein, Z protein) manipulate the host cell machinery to facilitate survival and spread of the virus without disturbing the basal cellular processes. Deep understanding of these strategies is inevitable for the development of approaches towards restricting the virus spread and/or preventing its harmful reactivation. This review summarizes the current status in this area and presents ideas emerging from existing data.
\end{abstract}

Keywords: lymphocytic choriomeningitis virus; arenaviruses; persistent infection

\section{Contents:}

1. The virus

1.1 Genome

1.2 Nucleoprotein

1.3 Z protein

1.4 Glycoproteins

2. Persistent infection

3. Strategies of persistence

3.1 Defective interfering RNAs

E-mail: virulama@savba.sk; phone: +421-2-59302439.

Abbreviations: ATF6 = activating transcription factor 6; DC = dendritic cells; $\mathrm{DG}=$ dystroglycan; $\mathrm{ECM}=$ extracellular matrix; eIF-4E/G = eukaryotic translation initiation factor $4 \mathrm{E}$ or $4 \mathrm{G}$; eIF$4 \mathrm{G}=$ eukaryotic translation initiation factor $4 \mathrm{G}$; GAPDH $=$ glyceraldehyd-3-phosphate dehydrogenase; GP1,2 = glycoprotein 1,2; $\mathrm{GPC}=$ glycoprotein precursor; IRE1 = inositol-requiring protein 1; IRF-3 = IFN regulatory factor 3; PERK = PKR-like ER kinase; $\mathrm{PML}=$ promyelocytic leukemia; $\mathrm{UPR}=$ unfolded protein response; $\mathrm{ZP}=\mathrm{Z}$ protein
3.2 Nucleoprotein phosphorylation

3.3 Reduction of translational repression

3.4 eIF-4F sequestration

3.5 ZP cooperation with P0 ribosomal protein

3.6 Unfolded protein response

3.7 PML redistribution

3.8 Impairment of budding

3.9 Cell-to-cell transmission

3.10 Nucleoprotein-mediated interferon suppression

3.11 Receptor control

3.12 Immune response control

4. Conclusions

\section{The virus}

Arenaviruses belong to the Arenaviridae family and were historically divided into two groups based on their distribution: New World (Tacaribe virus) and Old World (Lassa virus, LCMV) arenaviruses. The natural hosts of this virus family are 
rodents, which carry a persistent infection with continuous production of virus and little or no disease (Childs and Peters, 1993). The virus is usually transmitted by inhalation of aerosol from rodent excretes. Infection by lymphocytic chorimeningitis virus (LCMV) can produce illness with no apparent symptoms, febrile illness and sometimes can progress into aseptic meningitis or even fatal encephalitis (Jahrling and Peters, 1992). LCMV infection during pregnancy has been associated with spontaneous abortions and birth defects (Barton et al., 1993) or in transplant patients with fatal illness (Barry et al., 2008; Hadler et al., 2006; MMWR-Dispatch, 2005; Schafer et al., 2014; Waggoner et al., 2013). There is also evidence of reactivation of the persistent virus during hypoxia (Tomaskova et al., 2011). Physiologically, this can occur during heart attack, ischemia, stroke or pregnancy. Other arenaviruses such as Lassa, Junin, Machupo, Guaranito and Sabia virus cause sporadic outbreaks of severe and often fatal hemorrhagic fevers (Peters et al., 1996).

\subsection{Genome}

Genome of arenaviruses consists of two single-stranded RNA segments, which encode five protein products. The shorter segment (S) with an approximate size of 3-4 kb, contains two genes encoding a nucleoprotein and a glycoprotein precursor (GPC) that are posttranslationally cleaved into glycoprotein 1 (GP1) and glycoprotein 2 (GP2). The longer segment (L) of 7-8 kb contains genes encoding a viral RNA-dependent RNA polymerase (L protein) and an $11 \mathrm{~K} \mathrm{Z}$ protein containing a RING finger domain (ZP). Both RNA segments comprise the two genes in an opposite orientation, in non-overlapping reading frames. Both genes are separated by an intergenic region. Genomic RNAs exist in quasi-circular structures that are associated with NP (Cornu and de la Torre, 2001).

\subsection{Nucleoprotein}

Nucleoprotein, the most abundant viral protein in infected cell, is associated with viral RNA in the shape of beadlike structures that form nucleocapsid. Nucleocapsid and viral RNA polymerase constitute ribonucleoprotein (RNP) (Fuller-Pace and Southern, 1988). RNP is active in virus transcription and replication. Similarly to other RNA viruses, RNP is the minimum unit of LCMV infectivity. In infected cells, the full-length NP is localized exclusively in the cell cytoplasm, but a $28 \mathrm{~K}$ degradation fragment of NP accumulates in the nucleus as shown in the Pichinde virusinfected cells (Buchmeier et al., 2001).

\section{$1.3 \mathrm{Z}$ protein}

The ZP of arenaviruses is a multifunctional protein, however many of its functions are still unclear. ZP plays the role of structural and regulatory protein. It is incorporated into virions, suggesting that it may function immediately after infection (Salvato et al., 1992) as a regulatory protein. In studies of Tacaribe virus, it was proposed to function in the genome synthesis (Djavani et al., 1997) and later studies proposed that ZP inhibits transcription of the LCMV mini-genome (Cornu and de la Torre, 2001, 2002; Lopez et al., 2001). The presence of such negative regulatory protein could be one of the reasons why arenaviruses establish persistent infection in both their natural hosts and in cell cultures (Lopez et al., 2001).

$\mathrm{ZP}$ is a viral matrix protein, similar to $\mathrm{M}$ proteins of negative-stranded RNA viruses. It is the main driving force of virion budding (Salvato et al., 1992; Strecker et al., 2003). It contains a conserved RING-finger domain flanked by an Nterminal hydrophobic domain with myristoylation and phosphorylation site (Perez et al., 2004). The C-terminal portion of $\mathrm{ZP}$ contains proline-rich motifs that have been identified as late motifs in matrix proteins (Eichler et al., 2004; Freed, 2002). The integrity of the late motifs and the RING-finger domain is necessary for ZPs biological functions in the arenaviruses LCM and Lassa (Cornu and de la Torre, 2002; Perez et al., 2003; Strecker et al., 2003), whereas budding of Tacaribe virus does not depend on late motifs (Urata et al., 2009).

$\mathrm{ZP}$ can physically associate with both ribosomal $\mathrm{P}$ protein (Borden et al., 1998b) and eukaryotic translation initiation factor 4E (eIF-4E) (Campbell Dwyer et al., 2000). Both proteins are incorporated into virions (Borden et al., 1998a; Campbell Dwyer et al., 2000).

\subsection{Glycoproteins}

Glycoprotein is initially expressed as a precursor polypeptide, GPC, which is posttranslationally cleaved into two subunits, GP1 and GP2 (Buchmeier and Oldstone, 1979). GPC is cleaved by the cellular protein convertase subtilisin kexin isozyme 1 (SKI-1)/site 1 protease (S1P) (Beyer et al., 2003; Kunz et al., 2003; Lenz et al., 2001). The cellular protease SKI-1/S1P is involved not only in arenavirus GPC processing but also in regulation of the host cell's unfolded protein response (UPR) (Schröder and Kaufman, 2005; Ye et al., 2000). The amino-terminal cleavage product GP1 is a peripheral membrane protein non-covalently associated with the carboxy-terminal subunit GP2, which is an integral membrane protein (Burns and Buchmeier, 1991). GP1 interacts with the cellular receptor, whereas GP2 mediates fusion of the viral envelope with the cellular membrane (Borrow and Oldstone, 1992; Glushakova et al., 1990).

\section{Persistent infection}

Arenaviruses are non-cytolytic in cell culture and can easily establish persistent infection in rodent hosts. LCMV 
is a prototype virus of this family and a model for persistent infection. NP is uniformly distributed throughout the cytoplasm of persistently infected cells, whereas surface expression of GP is significantly down regulated relative to that in acutely infected cells (Buchmeier et al., 1980; Meyer and Southern, 1997). Defective interfering particles have also been implicated in LCMV persistence (Popescu et al., 1976). LCMV can readily establish persistent infection in vivo and long-term non-cytolytic infection in vitro, without apparent cellular pathology. Like many other persistent viruses, LCMV does not disturb the vital functions of the cell, but rather affects the "housekeeping" genes (de la Maza and Peterson, 1987). Persistent infection of neuroblastoma cells has no effect on the growth or protein synthesis, but the enzymes required for synthesis and degradation of acetylcholine are decreased. Mice in which the virus replication is restricted to the cells secreting growth hormone, develop persistent infection associated with systemic virus replication, growth hormone insufficiency, retarded development and severe hypoglycaemia (Valsamakis et al., 1987). On the other hand, persistent infection of $\beta$-cells of the Langerhans islets is associated with hypoglycaemia and abnormal glucose tolerance. Only minimal histological injury to the $\beta$-cells or islets was found in the absence of cell lysis or inflammation (Oldstone et al., 1984).
LCMV-related persistent infections had been neglected for a long time. Only in recent years, after several deaths of immunosuppressed transplant recipients (Barry et al., 2008; Hadler et al., 2006; MMWR-Dispatch, 2005; Schafer et al., 2014; Waggoner et al., 2013), has LCMV started to draw attention as a potentially dangerous agent. New diagnostic methods are being elaborated to detect not only antigens, but also antibodies against GP and NP in patients sera. However it is still difficult to demonstrate ongoing persistent LCMV infection.

LCMV and other arenaviruses which can establish persistent infection, have many ways how to modify, trick or hijack host cell functions for its own use or to escape and mislead the immune system. Here we introduce some of these virus strategies (Fig. 1).

\section{Strategies of persistence}

\subsection{Defective interfering RNAs}

Many animal or plant viruses produce defective interfering (DI) particles that contain viral genomes lacking genetic information for one or more functions necessary

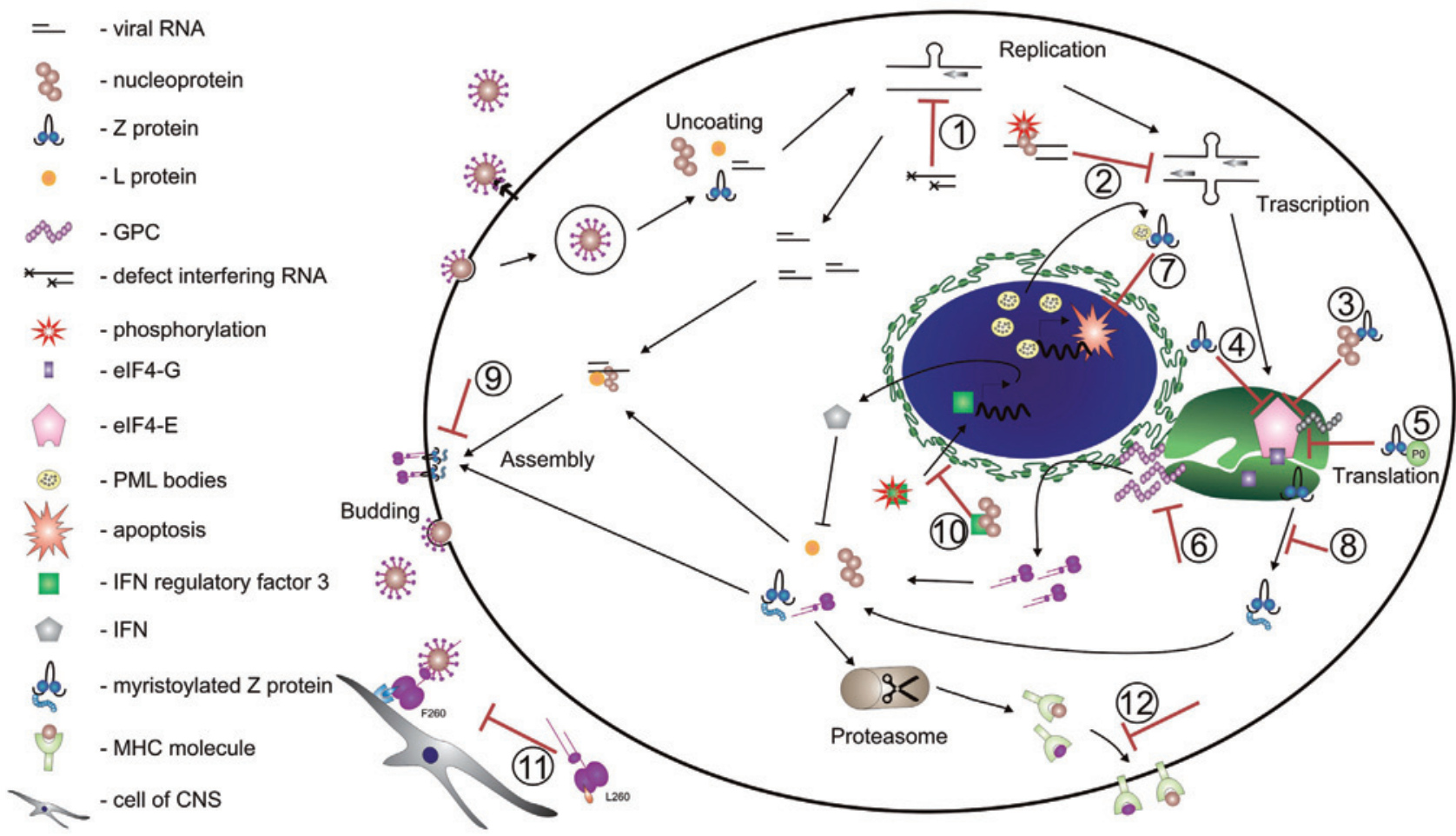

Fig. 1

Schematic presentation of viral life cycle in the cell and crutial points of persistence The numbers represent each mechanism of persistence as marked in the text. 
for independent replication (Holland, 1990). DI RNAs of RNA viruses have rearranged sequences or long deletions in protein-coding regions, but have at least one complete terminal sequence. Hence RNA templates support replication, but cannot support transcription of mRNAs that can direct the synthesis of functional protein (Meyer and Southern, 1997).

Viral RNAs with terminal deletions are also formed during LCMV persistent infection. Such truncated RNAs represent a new type of DI genome that contribute to establishment of LCMV persistence.

Some viral RNAs of S and L segment loose or gain small numbers of nucleotides at their termini during virus replication in acutely infected cells. There is still a large amount of full-length genomes, allowing for high expression of viral proteins and the release of infectious virions. However the terminally truncated RNAs can replicate but are not used as templates for transcription. After a few days of infection, more terminal nucleotides are lost and nucleotide gain does not balance this loss. New equilibrium between terminally truncated and full-length RNAs is established, initiating persistence (Meyer and Southern, 1997). The truncated, transcription incompetent RNAs interfere with the fulllength RNAs and thereby regulate protein expression and production of infectious virions. Some truncated RNAs may be repaired by the addition of nucleotides to obtain a full-length sequence, however this will disrupt the balance between transcription-competent and incompetent RNAs, leading to transient increase in the production of viral proteins. Fluctuation in the balance between the full-length and truncated RNAs, due to the gain and loss of nucleotides, provide a continuing, low level and sporadic source of newly functional RNAs which help to maintain the persistent state and perpetuate the long-term infection for the lifetime of the host (Meyer and Southern, 1997).

\section{2 Nucleoprotein phosphorylation}

Little is known about arenavirus nucleoprotein phosphorylation. The last available data are from 1988 and suggest that persistently infected cells overexpress NP phosphorylated by the virus-associated protein kinase. This raises the idea of the connection between NP phosphorylation and attenuation of viral genes during the shift from acute to persistent infection (Bruns et al., 1986, 1988). This is similar to other viruses, which regulate their own transcription and expression level by the NP phosphorylation (despite the fact that they do not establish persistent infection). For instance, NP phosphorylation of rabies virus (Rhabdoviridae) plays an important role in the regulation of viral transcription and replication, through modulation of the leader RNA encapsidation. The unphosphorylated NP, in comparison to the phosphorylated one, can encapsidate the rabies virus leader RNA and support transcription and replication of the rabies virus minigenome (Yang et al., 1999). Also, in another RNA virus, measles virus (Paramyxoviridae), NP phosphorylation downregulates viral trascriptional activity (Hagiwara et al., 2008).

In Marburg virus (Filoviridae), the phosphorylated NP is exclusively present in virus particles. Only the phosphorylated NP can form nucleocapsid complexes and interact with genomic RNA (Becker et al., 1994). This means that encapsidated RNA is no longer available for transcription. However, in the case of Marburg virus, the phosphorylated NP is encapsidated into the virions, while phosphorylated NP of LCMV is found only in persistently infected cells and not inside the virions.

In all three examples, the phosphorylation of the NP inhibited the transcription of viral RNA. Also, during LCMV infection the phosphorylation of NP could cause downregulation of transcription and contribute to the establishment of persistent infection. However, this assumption prompts further investigation.

\subsection{Reduction of translational repression}

It has been shown that NP closely associates with ZP inside the virion (Salvato et al., 1992), but not much is known about their cooperation inside the host cells. However, the $\mathrm{NP}$ can reduce ZP-mediated translational repression of certain cellular proteins, indicating that the interplay between the viral proteins may regulate function of $\mathrm{ZP}$ and perhaps may affect the establishment of persistent infection (Campbell Dwyer et al., 2000)(Fig. 2).

\section{4 eIF-4E sequestration}

Eukaryotic translation initiation factor $4 \mathrm{E}$ (eIF-4E) is involved in the nucleo-cytoplasmic transport of mRNAs. In the nucleus, eIF-4E influences transport of certain transcripts to the cytoplasm, and in the cytoplasm it loads transcripts onto polysomes (Rousseau et al., 1996). Apart from cytoplasmic distribution, eIF-4E forms nuclear bodies distinctive from nucleoli in non-exponentially growing cells (Lejbkowicz et al., 1992). Similar to ZP, eIF-4E has been shown to interact with the promyelocytic leukemia protein (PML) (Lai and Borden, 2000). ZP association with eIF-4E occurs in both nuclear and cytoplasmic fractions, but it is still unclear whether it directly interacts with their components (Campbell Dwyer et al., 2000).

$\mathrm{ZP}$ can post-transcriptionally repress translation of cyclin D1 (Campbell Dwyer et al., 2000), which together with cyclin $E$, is essential for the $G_{1} / S$ checkpoint transition of the cell cycle (Lai and Borden, 2000). Cyclin D1 translation depends on the eIF-4E translation factor, which promotes the nucleo-cytoplasmic transport of cyclin D1 mRNA and the 
preferential loading of transcripts onto polysomes (Rousseau et al., 1996). ZP inhibits cyclin D1 protein production by sequestration of eIF-4E and/or associated translation factors (Campbell Dwyer et al., 2000). Indeed, the repression is caused by changes in eIF-4E structure after binding with ZP. Under normal conditions, eIF4E interacts eIF4G translation factor through a consensus sequence on its dorsal surface. The eIF4E then binds 7-methyl guanosine $\left(\mathrm{m}^{7} \mathrm{G}\right)$ base of 5 'cap of mRNA, leading to the formation of the productive pre-initiation complex. The RING domains of ZP use the regions around the first zinc-binding site to bind the dorsal surface of eIF4E. These interactions drastically reduce the affinity of eIF4E to 5'cap of mRNA, probably through a conformational rearrangement of eIF4E, resulting in repression of mRNA translation (Kentsis et al., 2001).

In an acute LCMV infection, a complete virion can be produced within 6 to 10 hours after the entry of the virus to the cell. But later in the viral life cycle, when the level of NP is low and the level of ZP is high, ZP can interact with eIF-4E and shut-off translation of the 5 ' UTR-containing mRNAs. Such a self-regulating mechanism could be responsible for the non-cytolytic nature of arenaviral infection, slow growth in infected cells and perhaps a viral strategy for establishing persistent infection. Arenaviruses can thus limit their own translation to reduce the drastic impact on the host cell (Campbell Dwyer et al., 2000) (Fig. 2).

\subsection{ZP cooperation with P0 ribosomal protein}

Arenaviruses were initially thought to contain ribosomes based on their appearance in electron micrographs and the ability of virus preparations to polymerize radioactive amino acids (Leung and Rawls, 1977). Since then, it has been proven that ribosomal protein $\mathrm{P} 0$ is incorporated into the virion. However, the route of incorporation is still unclear. It does not appear to be directly mediated through the ZP for two reasons: (i) ZP does not redistribute nuclear $\mathrm{P} 0$ upon infection, and (ii) $\mathrm{Z}$ and $\mathrm{P} 0$ do not appear to coimmunoprecipitate, co-fractionate, or co-localize in the cytoplasm. The association of ZP and P0 in the nucleus and the appearance of $\mathrm{P} 0$ in the virion appear to be separate events. Therefore, the incorporation of $\mathrm{P} 0$ into virions may be a result of interaction with other viral proteins (Borden et al., 1998a).

Nevertheless, ZP can bind the nuclear fraction of P0 (Borden et al., 1998b), which has been associated with transcriptionally-coupled DNA excision repair and with nonspecific endonuclease activity. This suggests that P0 may be involved in the nucleic acid processing activities necessary for the LCMV replication (Borden et al., 1998b). P0 protein is also required for the ZP's repression activity, for which the eIF-4E association alone is not sufficient. The first zinc-binding site of the $\mathrm{Z}$ protein must make crucial protein

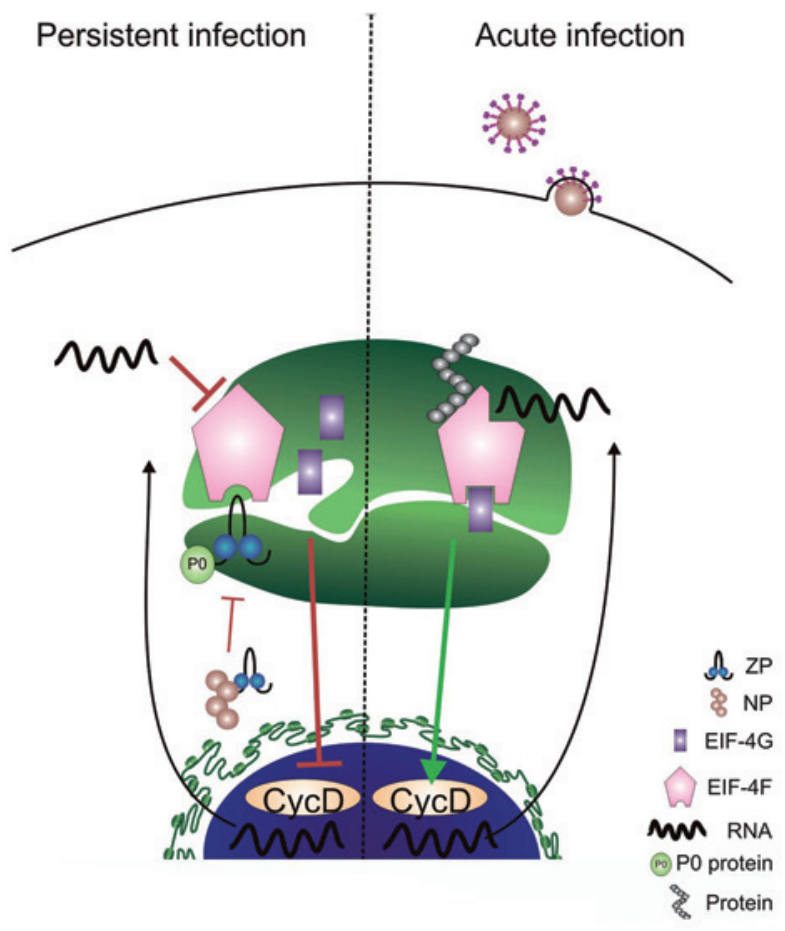

Fig. 2

Perturbation of translation: reduction of translation repression by NP, eIF-4E sequestration by $\mathrm{ZP}$ and ribosomal protein P0 cooperation with ZP

$\mathrm{NP}$ reduces $\mathrm{ZP}$ translation repression. In cooperation with $\mathrm{P0} \mathrm{ZP}$ can change the conformation of eIF-4E and reduce hosts translation of UTRcontaining mRNA.

interactions with other proteins, e.g. $\mathrm{P}$ proteins, which are also required for translation (Campbell Dwyer et al., 2000). Through the binding of $\mathrm{P} 0$-associated $\mathrm{Z}$ protein to eIF4E, it undergoes a conformation change and looses the capability to bind the mRNA. Via P0 association, ZP can shut-off translation of the 5'UTR containing mRNAs and the effect of maintaining the persistent infection recapitulates the one with eIF4E as mentioned above (Fig. 2).

\subsection{Unfolded protein response}

The entry of the nascent unfolded polypeptides into the ER exceeding its folding capacity can occur under a variety of conditions, including viral infection, and induce a process called cellular unfolded protein response (UPR) or ER stress response (Schröder and Kaufman, 2005). The initiator of UPR in mammalian cells is the ER chaperone protein GRP78/BiP, which interacts with three mediators: kinase/ endonuclease inositol-requiring protein 1 (IRE1), PKRlike ER kinase (PERK), and activating transcription factor 6 (ATF6). UPR is activated when BiP recognizes partially unfolded protein and PERK, IRE1 and ATF6 are released 
and activated. All three proteins activate a cascade of processes leading to the induction of UPR genes. The main role of UPR is to bring the folding capacity of the ER in line with the folding demand. However, if these protections fail and ER stress occurs for much longer periods of time, the UPR switches from a pro-survival to a pro-apoptotic signal and induces programmed cell death (Pasqual et al., 2011).

Many enveloped DNA and RNA viruses induce the UPR in mammalian cells. UPR induced by viruses usually involves proapototic signalling contributing to pathogenesis (Barry et al., 2010; Dimcheff et al., 2004; Medigeshi et al., 2007; Su et al., 2002; Williams and Lipkin, 2006). There are also viruses that can manipulate host cell's UPR to benefit their replication (Buchkovich et al., 2009; Chan et al., 2006; Isler et al., 2005; Pavio et al., 2003; Smith et al., 2006).

Expression of recombinant LCMV GPC, but not NP, ZP, and L expressed individually, activates the ATF6 branch of the cellular UPR (Pasqual et al., 2011). In acute LCMV infection, high levels of GPC induce ATF6-mediated responses. However, during the conversion to persistent infection, rapid down-regulation of GPC returns the UPR signalling back to basal levels. Pathways controlled by PERK and IRE1 remained unaffected during both acute and persistent infection. This selective and reversible activation of ATF6 during

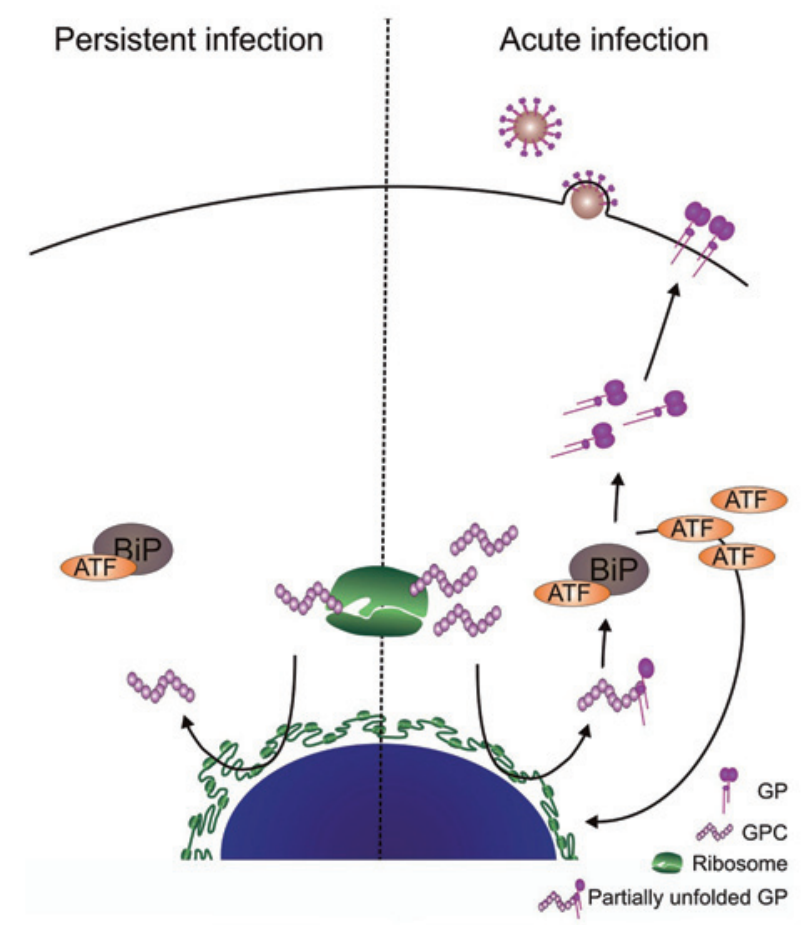

Fig. 3

Unfolded protein response. High levels of GPC can induce ATF6 regulated branch of the UTR

Rapid downregulation of GPC during persistent infection restores basal levels of UPR signaling. acute LCMV infection suggests that the virus evolved delicate GPC expression dynamics which enables the transient induction of ATF6 regulated UPR genes, which can increase the folding capacity in the ER. By this response, the host cells facilitate synthesis of high levels of viral GPC required for optimal virus production and protect the cell against virus-inflicted damage (Pasqual et al., 2011). GPC expression seems at all time points sufficiently low to prevent the induction of PERK and IRE1, whose activation contributes to translational arrest and pro-apoptotic signalling (Schröder and Kaufman, 2005). It is likely that LCMV infection causes transient hypersensitivity of the ATF6-regulated branch of the UPR and downregulation of the viral GPC expression restores normal levels of ATF6 responsiveness in persistently infected cells. This may allow the persistent virus to "merge" into the normal background level of ER stress of the host cell and may be crucial for the establishment of a long-term asymptomatic persistent infection (Pasqual et al., 2011). By modulating different branches of the UPR, the arenaviruses are capable of maintaining the protective responses favourable for their multiplication and evasion and/or inhibition of the pro-apoptotic pathways, and thereby can establish persistent infection (Pasqual et al., 2011) (Fig. 3).

\subsection{PML redistribution}

Promyelocytic leukemia (PML) forms multiprotein complexes referred to as PML nuclear bodies or nuclear domain 10 with several virus genome products: adenovirus type 5, HSV1, CMV, EBV, and papillomavirus (Melnick and Licht, 1999). PML nuclear bodies are formed in disease conditions. PML is implicated in pro-apoptotic (Takahashi et al., 2004) and antiviral responses (Regad and Chelbi-Alix, 2001), which may explain why PML nuclear bodies are frequent targets of viral infection (Garcia et al., 2010).

The $11 \mathrm{~K} \mathrm{Z}$ proteins of several arenaviruses have been sequenced including Lassa, Tacaribe, Pichinde, and LCM virus. RING domains of arenavirus ZPs are highly conserved (Djavani et al., 1997), so it is likely that all arenaviruses will have similar effects on PML nuclear bodies. PML is prominently expressed in reticuloendothelial cells (Flenghi et al., 1995), the most frequent targets of arenavirus infection (Salvato and Rai, 1996).

The interaction between PML protein and $\mathrm{ZP}$ is the first reported interaction between an arenavirus protein and a host protein (Borden et al., 1998b). Z protein directly binds to the N-terminal region of PML (Borden et al., 1998b) and redistributes them from the nucleus, but leaves other host cell proteins, such as ribosomal $\mathrm{P}$ proteins, unaffected (Borden et al., 1998a). ZP alone is sufficient to redistribute PML bodies to cytoplasm (Borden et al., 1998b). PML may be moved to the cytoplasm to prevent it from promoting apoptosis, thus enabling the survival of virus-loaded cells and allowing the 
virus to establish long-term infections (Borden et al., 1997, 1998a). Alternatively, the fact that the ZP targets P ribosomal proteins that are the partners of PML suggests viral hijacking of the cellular translational machinery, of which PML may be a component (Borden et al., 1998a). Moreover, interaction between PML and ZP has been considered deleterious to virus replication because LCMV grows to higher titers in PML-negative cells (Djavani et al., 2001).

The fact that arenaviruses require the cell nucleus for replication even though they replicate in the cytoplasm (Banerjee et al., 1975) makes PML a candidate for the nuclear component. PML distribution to cytoplasm is often an anti-apoptotic event (Le et al., 1996) suggesting a simple mechanism to explain the noncytopathic nature of arenaviruses (Borden et al., 1998a) (Fig. 4).

\subsection{Impairment of budding}

$\mathrm{ZP}$ is highly membrane-associated, but the nature of this tight interaction with the plasma membrane remains still unknown since ZP is lacking a characteristic hydrophobic transmembrane domain (Strecker et al., 2003). Amino acid sequences of several arenaviral ZPs revealed the presence of myristoylation site. By comparing 17 sequences of arenaviral ZPs, including LCMV or arenaviruses causing hemorrhagic fevers, a presence of a conserved glycine residue on position 2 in the context of a consensus myristoylation signal was found (Farazi et al., 2001). Myristoylation is a nonreversible covalent attachment of myristate, a 14-carbon saturated fatty acid to the N-terminal glycine. Disruption of the myristoylation signal causes prevention of myristic acid incorporation and impairment of budding activity (Perez et al., 2004). This aspect arises a question, whether the impairment of ZP myristoylation could play a role in establishing persistent infection (Fig. 4).

\subsection{Cell-to-cell transmission}

In recent years we have identified a protein that interacts with NP as type II keratin 1 (Labudova et al., 2009). Keratin 1 is connected to desmoplakin, one of the building blocks of desmosomes (Meng et al., 1997). Desmosomes are major components of the intercellular junctional complex of epithelia. They are formed on the plasma membrane of adjacent cells upon induction of cell-cell contact, and play important roles in cell adhesion and in maintenance of the structural and functional interaction of adjacent cell.

It has already been proven that lymphocytic choriomeningitis virus can establish long-term non-cytolytic infection in vitro and spread in culture by cell-to-cell contacts (Zavada and Zavadova, 1991). As demonstrated using the LCMV strain MX, during persistent infection, the viral particles are not released to medium, so the uninfected cells could not be

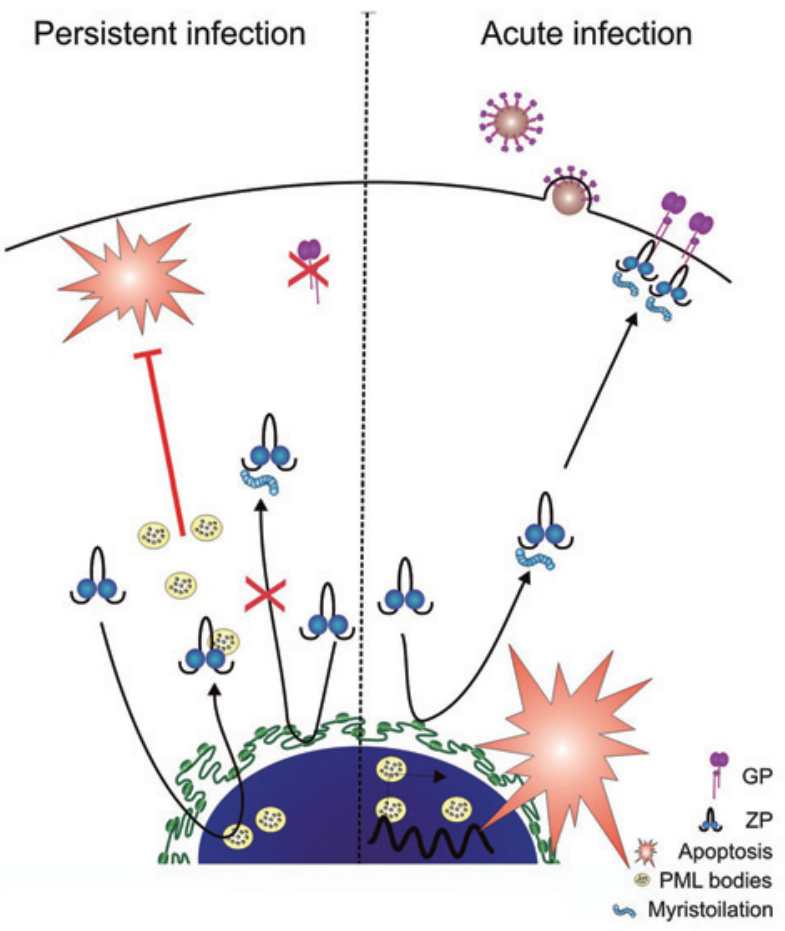

Fig. 4

PML redistribution and impairment of budding. Redistribution of PML from nucleus by $\mathrm{ZP}$ protects the cell from apoptosis Lack of myristoylation on ZP reduces the ability of virion to budd from the cell.

infected by the regular virus-receptor interaction. Interaction with keratin 1 enables NP (in the form of ribonucleoprotein) to be distributed to the places where two cells are tightly connected by desmosome. This gives NP the opportunity to cross the intercellular gap inside (tunneling nanotubes, actin tails) or outside the cell. This type of virus spreading is very important for maintaining persistent infection. Cell-to-cell spread is typically rapid and efficient, because viruses and their cell surface receptors are in close proximity, and viruses can move across the narrow spaces between cells. What is very important for persistent adaptation is that during such spread in vivo, the viral particles are protected from the effects of neutralizing antibodies and other immune system components by tight and adherens junctions (Johnson and Huber, 2002) (Fig. 5).

\subsection{Nucleoprotein-mediated interferon suppression}

The adaptive immune response provides the host with a robust and long-term antiviral defence, but it does not reach full efficacy for days or weeks. In contrast, the host innate response is elicited very rapidly upon infection and provides the host with early protection and critically influ- 


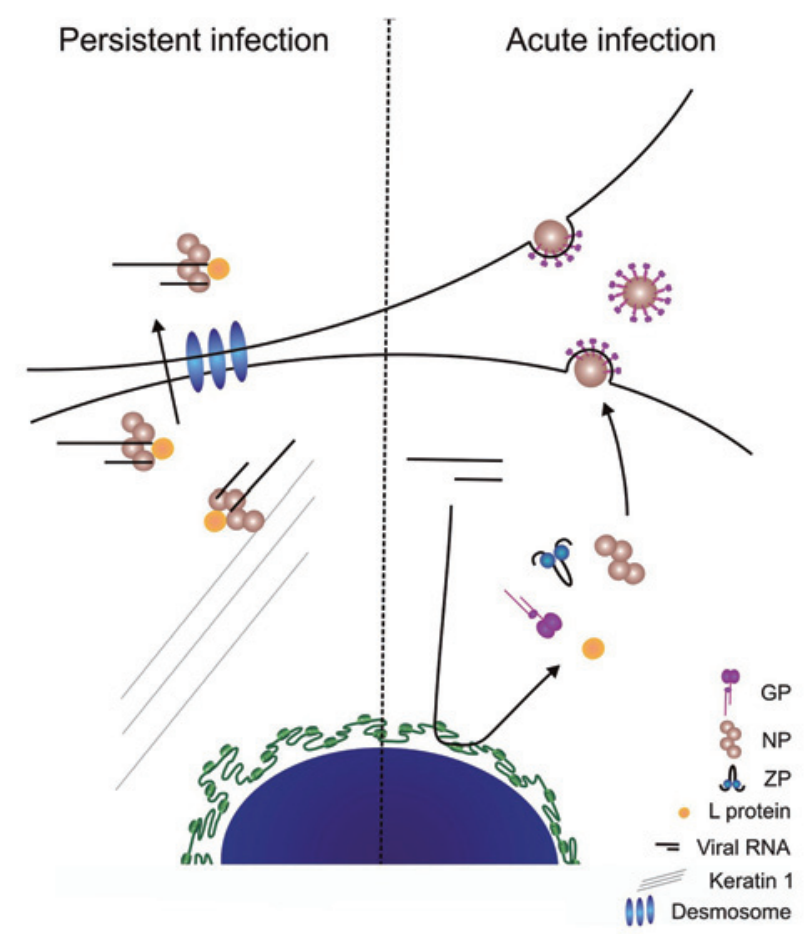

Fig. 5

Cell-to-cell transmission

Virus can spread to other cells through the intercellular gap or by cellular protrusions, were it is in close proximity to receptor and it is protected from immune system.

ences the subsequent adaptive immune response (Beutler, 2004). Type I interferons (IFN) play key roles in both the innate and adaptive immune response of the host against viral infections (Bonjardim, 2005). Blockage of IFN I signalling using a type 1 interferon receptor neutralizing antibody reduces immune system activation, decreases expression of negative immune regulatory molecules and restores lymphoid architecture in mice persistently infected with LCMV. IFN I blockade both prior to and following the establishment of persistent virus infection results in enhanced virus clearance (Teijaro et al., 2013). LCMV NP blocks the nuclear translocation and transcriptional activity of IFN regulatory factor 3 (IRF-3), which results in the robust inhibition of type I IFN production. Nuclear translocation is a hallmark of IRF-3 activation. The lack of IRF-3 nuclear translocation in the presence of LCMV NP would suggest the inhibition of upstream processes associated with IRF-3 phosphorylation. This IFN-counteracting activity of the arenavirus NP may contribute to the failure of the host innate antiviral response to control the multiplication of pathogenic arenaviruses (Martinez-Sobrido et al., 2006) and establishment of persistent infection (Fig. 6).

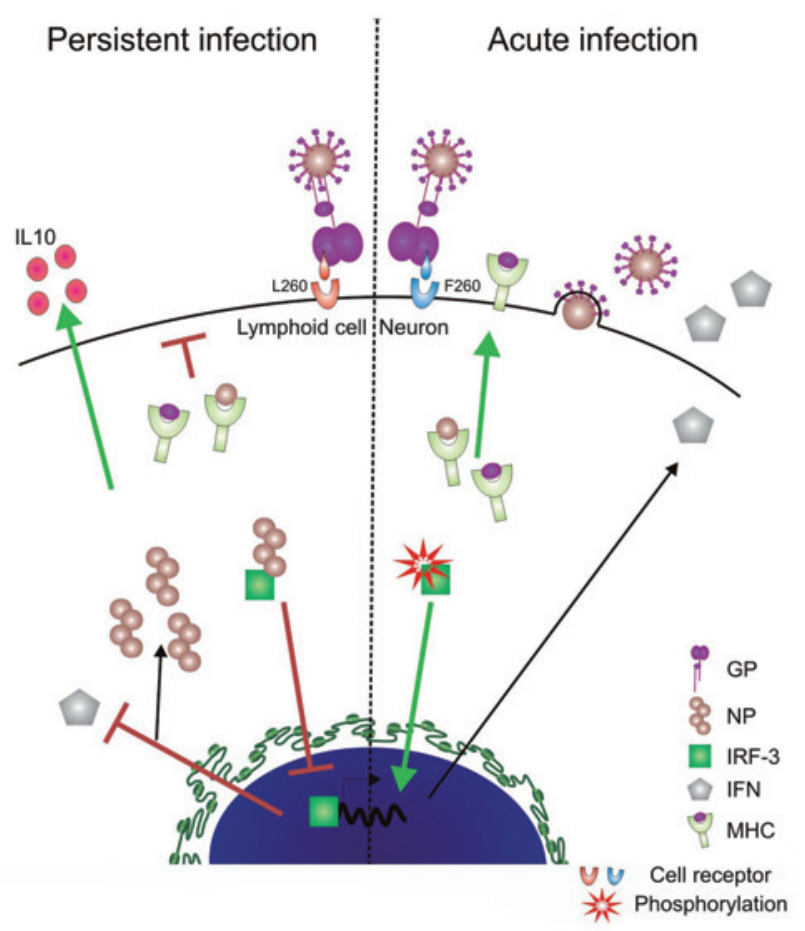

Fig. 6

Controlling the immune system: NP-mediated interferon suppression, receptor control and immune response control

NP blocks the nuclear translocation and transcriptional activity of IFN regulatory factor 3. Lymphoid variants of the virus with $260 \mathrm{~L}$ residue on GP1 failed to generate CTL response and clear the infection and therefore they stablish persistent infection. Arenaviruses can ablate DCs function and lack of DCs presenting the viral antigen will help to develop viral persistence.

\subsection{Receptor control}

The cellular receptor for Old World arenaviruses is alphadystroglycan ( $\alpha-D G)$. Arenavirus binding to the $\alpha$-DG receptor critically depends on its protein O-mannosylation, but not on more generic O-linked glycans (Rojek et al., 2007).

Cell types that adjoin extracellular matrix (ECM) structures, like epithelial cells, hepatocytes, endothelial cells, and fibroblasts, express significant levels of functionally glycosylated $\alpha$-DG and are highly susceptible to infection. In contrast, the established human B- and T-cell lines tested express a form of $\alpha-D G$ that lacks a detectable functional modification, rendering these cell types highly resistant (Rojek et al., 2007). DCs express the greatest amount of a-DG on their surfaces (Sevilla et al., 2000).

LCMV strains from CNS (CNS variants, LCMV ARM 53b) of adult mice, in which the virus persistently infects only neurons, induce a potent and specific anti-LCMV CTL response and clear the infection within two weeks. In contrast, isolates from lymphoid tissues and cells (lymphoid variants, LCMV Clone 13) fail to generate a CTL response, 
fail to clear the infection and can therefore establish a persistent infection (Oldstone and Campbell, 2011).

By analyzing the sequences of CNS and lymphoid variants, a single mutation at amino acid position 260 of GP1 was found to be associated with each variant. Lymphoid variants commonly encode an aliphatic small amino acid (leucine, isoleucine, valine), whereas CNS variants have a bulky aromatic phenylalanine at this position of GP1 (Oldstone and Campbell, 2011).

Virus-binding to $a-D G$ requires a displacement of the bound ECM molecule (Kunz et al., 2001) and those viral strains that bind $\alpha-D G$ with the highest affinity and displace ECM molecules, preferentially infect DCs and alter their ability to initiate an effective immune response (Oldstone, 2002; Sevilla et al., 2000; Smelt et al., 2001). Lymphoid variants out-compete the ECM molecule laminin for binding, while the CNS variants consistently fail to displace it (Kunz et al., 2001). All these events contribute to the ability of the lymphoid variants of LCMV to establish and maintain persistent infection in the host (Sullivan et al., 2011).

The recognition of a highly conserved functional glycan structure on $\alpha-D G$ may have been advantageous during the virus-host co-evolution and is likely to be one reason for the broad host range and tissue tropism of arenaviruses (Rojek et al., 2006; Spiropoulou et al., 2002) (Fig. 6).

Also, the state of the infection may be depend on the sequence of GP2 cytoplasmic tail. LCMV expressing Lassa virus GP could prolong viremia in mice to 2 weeks duration and replacement of entire sequence of Lassa virus cytosolic tail resulted in increased viral titers and delayed clearance of the virus (Sommerstein et al., 2014).

However, by reverse genetics it has been found, that not only mutation of GP but also mutation in L protein 1079 (L1079) is responsible for chronic infection caused by LCMV strain Clone 13. L1079 mutation increased viral RNA levels by vector infection in vivo (Flatz et al., 2010) and thus, in the absence of spreading infectivity or T-cell exhaustion. This shows that enhanced replication with resulting increase in viral loads is the cause rather than the consequence of viral persistence, T-cell exhaustion, and generalized immunosuppression (Bergthaler et al., 2010).

\subsection{Immune response control}

Viruses use a multi-pronged strategy to disrupt DC function, thereby subduing the antiviral immune response and promoting their own long-term survival (Oldstone and Campbell, 2011). By altering and modulating the immune responses, the host is no longer able to clear the virus and can tolerate its presence, thereby establishing the persistent infection.

Arenaviruses can ablate DCs functions and thereby establish viral persistence. Early (day 4,5) after the infec- tion, a small but active set of LCMV-specific CD8 ${ }^{+}$CTLs is generated that is able to destroy the DCs presenting viral antigen on their surfaces. The lack of DCs presenting the viral antigen helps to develop persistent infection (Borrow et al., 1995). Lymphoid variants can outcompete the ECM protein laminin for binding to $a-D G$ receptors on DCs as described above and infect many remaining DCs (Kunz et al., 2001; Sevilla et al., 2000). Once the virus is internalized into the DCs, transcriptional and translational machinery is selectively distorted and the molecules needed for antigen presentation are down-regulated. This disables the arming and expansion of $\mathrm{T}$ cell population that would normally eliminate the viral infection (Kunz et al., 2001; Sevilla et al., 2000; Smelt et al., 2001). Also, the infected DCs are induced by the virus to produce immune response suppressors such as IL-10, which may also down-regulate class I MHC (Brooks et al., 2008). In favour of this, blockade of IL-10 may cause strain dependent reversal of chronic to resolved infection (Richter et al., 2013). The virus prevents infected progenitor cells from maturing into DCs and migrating to the spleen thereby preventing the host from producing new DCs (Sevilla et al., 2004) (Fig. 6). Type 1 interferon being upstream of hundreds of inflammatory genes, may be responsible for generating the hyper-activated immune environment during virus persistence. As mentioned above, NP of LCMV blocks nuclear translocation of IRF-3 and leads to the failure of IFN I production. IFN I blockade increases viral NP expression in DCs and macrophages, increases their frequency and number and also increases DCs with immune-stimulatory phenotype, but decreases production of multiple pro-inflammatory cytokines and chemokines during persistent infection (Teijaro et al., 2013).

\section{Conclusions}

Arenaviruses use all their components (RNA and all its proteins) to modify cell nature or pathways to establish or maintain the persistent status in vivo and long-term noncytolytic status in vitro. All the mechanisms that lead to the establishment of persistent infection are part of evolutionary relationships between the host cell and virus. Despite the fact that cells and the host organisms possess different antiviral mechanisms, viruses have developed ways to overcome these mechanisms and develop persistent infection. Understanding these mechanisms brings not only better knowledge of host-virus interactions, but also presents new opportunities for combating such persistent infections.

Acknowledgement. This work was supported by VEGA-2/0146/12 grant from Scientific Grant Agency of Ministry of Education of the Slovak Republic. 


\section{References}

Banerjee SN, Buchmeier M, Rawls WE, Intervirology 6, 190-196, 1975. http://dx.doi.org/10.1159/000149472

Barry A, Gunn J, Tormey P, McCarthy T, Pendarvis J, Delmonico F, Sussman L, Fitzpatrick S, Gautam A, Sulis C, Wong M, Pillai S, Arya M, Stillman I, Wright SB, Karp S, Goodell P, DeMaria A, Brown C, Cumming M, Matyas B, Hull M, Schillie S, Brief Report: Massachusetts, 2008. MMWR 57, 799-801, 2008.

Barry G, Fragkoudis R, Ferguson MC, Lulla A, Merits A, Kohl A, Fazakerley JK, J. Virol. 84, 7369-7377, 2010. http://dx.doi. org/10.1128/JVI.02310-09

Barton LL, Budd SC, Morfitt WS, Peters CJ, Ksiazek TG, Schindler RF, Yoshino MT, Pediatr. Infect. Dis. J. 12, 942-946, 1993. http://dx.doi.org/10.1097/00006454-199311000-00010

Becker S, Huppertz S, Klenk HD, Feldmann H, J. Gen. Virol. 75, 809-818, 1994. Bergthaler A, Flatz L, Hegazy AN, Johnson S, Horvath E, Lohning M, Pinschewer DD, Proc. Natl. Acad. Sci. USA 107, 21641-21646, 2010.

Beutler B, Mol. Immunol. 40, 845-859, 2004. http://dx.doi. org/10.1016/j.molimm.2003.10.005

Beyer WR, Popplau D, Garten W, von Laer D, Lenz O, J. Virol. 77, 2866-2872, 2003. http://dx.doi.org/10.1128/ JVI.77.5.2866-2872.2003

Bonjardim CA, Microbes Infect. 7, 569-578, 2005. http://dx.doi. org/10.1016/j.micinf.2005.02.001

Borden KL, Campbell Dwyer EJ, Salvato MS, FEBS Lett. 418, 30-34, 1997. http://dx.doi.org/10.1016/S0014-5793(97)01344-6

Borden KL, Campbell Dwyer EJ, Carlile GW, Djavani M, Salvato MS, J. Virol. 72, 3819-3826, 1998a.

Borden KL, Campbell Dwyer EJ, Salvato MS, J. Virol. 72, 758-766, 1998b.

Borrow P, Evans CF, Oldstone MB, J. Virol. 69, 1059-1070, 1995.

Borrow P, Oldstone MB, J. Virol. 66, 7270-7281, 1992.

Brooks DG, Ha SJ, Elsaesser H, Sharpe AH, Freeman GJ, Oldstone MB, Proc. Natl. Acad. Sci. USA 105, 20428-32043, 2008. http://dx.doi.org/10.1073/pnas.0811139106

Bruns M, Gessner A, Lother H, Lehmann-Grube F, Virology 166, 133-139, 1988. http://dx.doi.org/10.1016/0042-6822(88)90154-7

Bruns M, Zeller W, Rohdewohld H, Lehmann-Grube F, Virology 151, 77-85, 1986. http://dx.doi.org/10.1016/0042-6822(86)90105-4

Buchkovich NJ, Maguire TG, Paton AW, Paton JC, Alwine JC, J. Virol. 83, 11421-11428, 2009. http://dx.doi.org/10.1128/ JVI.00762-09

Buchmeier MJ, Bowen MD, Peters CJ, pp. 1521-1551. In B. N. Fields, D. M. Knipe, and P. M. Howley (Eds): Fields Virology, Lippincott-Williams \& Wilkins Publishers, Philadelphia, 2001.

Buchmeier MJ, Oldstone MB, Virology 99, 111-120, 1979. http:// dx.doi.org/10.1016/0042-6822(79)90042-4

Buchmeier MJ, Welsh RM, Dutko FJ, Oldstone MB, Adv. Immunol. 30, 275-331, 1980. http://dx.doi.org/10.1016/S0065-2776$\underline{(08) 60197-2}$
Burns JW, Buchmeier MJ, Virology 183, 620-629, 1991. http:// dx.doi.org/10.1016/0042-6822(91)90991-I

Campbell Dwyer EJ, Lai H, MacDonald RC, Salvato MS, Borden KL, J. Virol. 74, 3293-3300, 2000. http://dx.doi.org/10.1128/ LI.74.7.3293-3300.2000

Chan CP, Siu KL, Chin KT, Yuen KY, Zheng B, Jin DY, J. Virol. 80 , 9279-9287, 2006. Childs J, Peters C, pp. 331-384. In M. S. Salvato (Ed.): The Arenaviridae, Plenum, New York, 1993.

Cornu TI, de la Torre JC, J. Virol. 75, 9415-9426, 2001. http://dx.doi. org/10.1128/JVI.75.19.9415-9426.2001

Cornu TI, de la Torre JC, J. Virol. 76, 6678-6688, 2002. http://dx.doi. org/10.1128/JVI.76.13.6678-6688.2002

de la Maza LM, Peterson EM, Elsevier Science Publisher. Amsterdam, 1987.

Dimcheff DE, Faasse MA, McAtee FJ, Portis JL, J. Biol. Chem. 279, 33782-33790, 2004. http://dx.doi.org/10.1074/jbc. M403304200

Djavani M, Lukashevich IS, Sanchez A, Nichol ST, Salvato MS, Virology 235, 414-418, 1997. http://dx.doi.org/10.1006/ viro.1997.8722

Djavani M, Rodas J, Lukashevich IS, Horejsh D, Pandolfi PP, Borden KL, Salvato MS, J. Virol. 75, 6204-6208, 2001. http:// dx.doi.org/10.1128/JVI.75.13.6204-6208.2001

Eichler R, Strecker T, Kolesnikova L, ter Meulen J, Weissenhorn W, Becker S, Klenk HD, Garten W, Lenz O, Virus. Res. 100, 249-255, 2004. http://dx.doi.org/10.1016/j. virusres.2003.11.017

Farazi TA, Waksman G, Gordon JI, J. Biol. Chem. 276, 39501-39504, 2001. http://dx.doi.org/10.1074/jbc.R100042200

Flatz L, Hegazy AN, Bergthaler A, Verschoor A, Claus C, Fernan$\operatorname{dez}$ M, Gattinoni L, Johnson S, Kreppel F, Kochanek S, Broek M, Radbruch A, Levy F, Lambert PH, Siegrist CA, Restifo NP, Lohning M, Ochsenbein AF, Nabel GJ, Pinschewer DD, Nat. Med. 16, 339-345, 2010. http://dx.doi. org/10.1038/nm.2104

Flenghi L, Fagioli M, Tomassoni L, Pileri S, Gambacorta M, Pacini R, Grignani F, Casini T, Ferrucci PF, Martelli MF, Pelicci PG, Falini B, Blood 85, 1871-1880, 1995.

Freed EO, J. Virol. 76, 4679-4687, 2002. http://dx.doi.org/10.1128/ JVI.76.10.4679-4687.2002

Fuller-Pace FV, and Southern PJ, Virology 162, 260-263, 1988. http://dx.doi.org/10.1016/0042-6822(88)90419-9

Garcia CC, Topisirovic I, Djavani M, Borden KL, Damonte EB, Salvato MS, Biochem. Biophys. Res. Commun. 393, 625-630, 2010. http://dx.doi.org/10.1016/j.bbrc.2010.02.040

Glushakova SE, Lukashevich IS, and Baratova LA, FEBS Lett. 269, 145-147, 1990. http://dx.doi.org/10.1016/0014-5793(90) $81140-\mathrm{I}$

Hadler L, Nelson R, Mshar P, and Sosa LE, MMWR 55, 398-399, 2006.

Hagiwara K, Sato H, Inoue Y, Watanabe A, Yoneda M, Ikeda F, Fujita K, Fukuda H, Takamura C, Kozuka-Hata H, Oyama M, Sugano S, Ohmi S, Kai C, Proteomics 8, 1871-1879, 2008. http://dx.doi.org/10.1002/pmic.200701051

Holland JJ, pp. 151-165. In B. N. Fields, D. M. Knipe (Eds): Virology, Raven Press, New York, 1990. 
Isler JA, Maguire TG, Alwine JC, J. Virol. 79, 15388-15397, 2005. http://dx.doi.org/10.1128/JVI.79.24.15388-15397.2005

Jahrling PB, Peters CJ, Arch. Pathol. Lab. Med. 116, 486-488, 1992.

Johnson DC, Huber MT, J. Virol. 76, 1-8, 2002. http://dx.doi. org/10.1128/JVI.76.1.1-8.2002

Kentsis A, Dwyer EC, Perez JM, Sharma M, Chen A, Pan ZQ, Borden KL, J. Mol. Biol. 312, 609-623, 2001. http://dx.doi. org/10.1006/jmbi.2001.5003

Kunz S, Edelmann KH, de la Torre JC, Gorney R, Oldstone MB, Virology 314, 168-178, 2003. http://dx.doi.org/10.1016/ $\underline{\text { S0042-6822(03)00421-5 }}$

Kunz S, Sevilla N, McGavern DB, Campbell KP, Oldstone MB, J. Cell. Biol. 155, 301-310, 2001. http://dx.doi.org/10.1083/ jcb.200104103

Labudova M, Tomaskova J, Skultety L, Pastorek J, Pastorekova S, J. Virol. 83, 7842-7849, 2009. http://dx.doi.org/10.1128/ JVI.00309-09

Lai HK, Borden KL, Oncogene 19, 1623-1634, 2000. http://dx.doi. org/10.1038/sj.onc. 1203473

Le XF, Yang P, Chang KS, J. Biol. Chem. 271, 130-135, 1996. http:// dx.doi.org/10.1074/jbc.271.1.130

Lejbkowicz F, Goyer C, Darveau A, Neron S, Lemieux R, Sonenberg N, Proc. Natl. Acad. Sci. USA 89, 9612-9616, 1992. http:// dx.doi.org/10.1073/pnas.89.20.9612

Lenz O, ter Meulen J, Klenk HD, Seidah NG, Garten W, Proc. Natl. Acad. Sci. U S A 98, 12701-12705, 2001. http://dx.doi. org/10.1073/pnas.221447598

Leung WC, Rawls WE, Virology 81, 174-176, 1977. http://dx.doi. org/10.1016/0042-6822(77)90070-8

Lopez N, Jacamo R, Franze-Fernandez MT, J. Virol. 75, 12241-51, 2001. http://dx.doi.org/10.1128/JVI.75.24.12241-12251.2001

Martinez-Sobrido L, Zuniga EI, Rosario D, Garcia-Sastre A, de la Torre JC, J. Virol. 80, 9192-9199, 2006. http://dx.doi. org/10.1128/JVI.00555-06

Medigeshi GR, Lancaster AM, Hirsch AJ, Briese T, Lipkin WI, Defilippis V, Fruh K, Mason PW, Nikolich-Zugich J, Nelson JA, J. Virol. 81, 10849-10860, 2007. http://dx.doi. org/10.1128/JVI.01151-07

Melnick A, Licht JD, Blood 93, 3167-3215, 1999.

Meng JJ, Bornslaeger EA, Green KJ, Steinert PM, Ip W, J. Biol. Chem. 272, 21495-21503, 1997 http://dx.doi.org/10.1074/ jbc. 272.34 .21495

Meyer BJ, Southern PJ, J. Virol. 71, 6757-6764, 1997.

MMWR-Dispatch, MMWR 54, 537-539, 2005.

Oldstone MB, Curr. Top. Microbiol. Immunol. 263, 83-117, 2002. http://dx.doi.org/10.1007/978-3-642-56055-2 6

Oldstone MB, Campbell KP, Virology 411, 170-179, 2011. http:// dx.doi.org/10.1016/j.virol.2010.11.023

Oldstone MB, Southern P, Rodriquez M, Lampert P, Science 224, 1440-3, 1984. Pasqual G, Burri DJ, Pasquato A, de la Torre JC, Kunz S, J. Virol. 85, 1662-70, 2011.

Pavio N, Romano PR, Graczyk TM, Feinstone SM, Taylor DR, J. Virol. 77, 3578-85, 2003. http://dx.doi.org/10.1128/ JVI.77.6.3578-3585.2003

Perez M, Craven RC, de la Torre JC, Proc. Natl. Acad. Sci. USA 100, 12978-83, 2003. http://dx.doi.org/10.1073/ pnas. 2133782100
Perez M, Greenwald DL, de la Torre JC, J. Virol. 78, 11443-8, 2004. http://dx.doi.org/10.1128/JVI.78.20.11443-11448.2004

Peters CJ, Buchmeier MJ, Rollin PE, Ksiazek TG, Lippincott-Raven. Philadelphia, 1996.

Popescu M, Schaefer H, Lehmann-Grube F, J. Virol. 20, 1-8, 1976.

Regad T, Chelbi-Alix MK, Oncogene 20, 7274-86, 2001. http:// dx.doi.org/10.1038/sj.onc. 1204854

Richter K, Perriard G, Oxenius A, Eur. J. Immunol. 43, 649-654, 2013. http://dx.doi.org/10.1002/eji.201242887

Rojek JM, Spiropoulou CF, Campbell KP, Kunz S, J. Virol. 81, 56855695, 2007. http://dx.doi.org/10.1128/JVI.02574-06

Rojek JM, Spiropoulou CF, Kunz S, Virology 349, 476-491, 2006. http://dx.doi.org/10.1016/j.virol.2006.02.033

Rousseau D, Kaspar R, Rosenwald I, Gehrke L, Sonenberg N, Proc. Natl. Acad. Sci. USA 93, 1065-1070, 1996. http://dx.doi. org/10.1073/pnas.93.3.1065

Salvato MS, Rai SK, In B. W. J. Mahy (Ed.): Topley and Wilson's microbiology and microbial infections. Arnold Publishing, London, 1996, pp. 629-650.

Salvato MS, Schweighofer KJ, Burns J, Shimomaye EM, Virus. Res. 22, 185-198, 1992. http://dx.doi.org/10.1016/0168-1702(92) $90050-\mathrm{I}$

Schafer IJ, Miller R, Stroher U, Knust B, Nichol ST, Rollin PE, MMWR Morb. Mortal. Wkly. Rep. 63, 249, 2014.

Schröder M, Kaufman RJ, Annu. Rev. Biochem. 74, 739789, 2005. http://dx.doi.org/10.1146/annurev. biochem.73.011303.074134

Sevilla N, Kunz S, Holz A, Lewicki H, Homann D, Yamada H, Campbell KP, de La Torre JC, Oldstone MB, J. Exp. Med. 192, 1249-1260, 2000. http://dx.doi.org/10.1084/ jem.192.9.1249

Sevilla N, McGavern DB, Teng C, Kunz S, Oldstone MB, J. Clin. Invest. 113, 737-745, 2004. http://dx.doi.org/10.1172/ LCI20243

Smelt SC, Borrow P, Kunz S, Cao W, Tishon A, Lewicki H, Campbell KP, Oldstone MB, J. Virol. 75, 448-457, 2001. http://dx.doi. org/10.1128/JVI.75.1.448-457.2001

Smith JA, Schmechel SC, Raghavan A, Abelson M, Reilly C, Katze MG, Kaufman RJ, Bohjanen PR, Schiff LA, J. Virol. 80, 2019-2033, 2006. http://dx.doi.org/10.1128/ JVI.80.4.2019-2033.2006

Sommerstein R, Ramos da Palma J, Olschlager S, Bergthaler A, Barba L, Lee BP, Pasquato A, Flatz L, J. Virol. 88, 83408348, 2014. http://dx.doi.org/10.1128/JVI.00236-14

Spiropoulou CF, Kunz S, Rollin PE, Campbell KP, Oldstone MB, J. Virol. 76, 5140-516, 2002. http://dx.doi.org/10.1128/ JVI.76.10.5140-5146.2002

Strecker T, Eichler R, Meulen J, Weissenhorn W, Dieter Klenk H, Garten W, Lenz O, J. Virol. 77, 10700-10705, 2003. http:// dx.doi.org/10.1128/JVI.77.19.10700-10705.2003

Su HL, Liao CL, Lin YL, J. Virol. 76, 4162-4171, 2002. http://dx.doi. org/10.1128/JVI.76.9.4162-4171.2002

Sullivan BM, Emonet SF, Welch MJ, Lee AM, Campbell KP, de la Torre JC, Oldstone MB, Proc Natl Acad Sci USA 108, 2969-2974, 2011. http://dx.doi.org/10.1073/ pnas. 1019304108 
Takahashi Y, Lallemand-Breitenbach V, Zhu J, de The H, Oncogene 23, 2819-2824, 2004. Teijaro JR, Ng C, Lee AM, Sullivan BM, Sheehan KC, Welch M, Schreiber RD, de la Torre JC, Oldstone MB, Science 340, 207-211, 2013.

Tomaskova J, Oveckova I, Labudova M, Lukacikova L, Laposova K, Kopacek J, Pastorekova S, Pastorek J, J. Virol. 85, 1306913076, 2011. http://dx.doi.org/10.1128/JVI.00829-11

Urata S, Yasuda J, de la Torre JC, J. Virol. 83, 12651-5, 2009. http:// dx.doi.org/10.1128/JVI.01012-09

Valsamakis A, Riviere Y, Oldstone MB, Virology 156, 214-220, 1987. http://dx.doi.org/10.1016/0042-6822(87)90400-4
Waggoner JJ, Soda EA, Deresinski S, Clin Infect Dis 57, 1182-8, 2013. http://dx.doi.org/10.1093/cid/cit456

Williams BL, Lipkin WI, J. Virol. 80, 8613-8626, 2006. http://dx.doi. org/10.1128/JVI.00836-06

Yang J, Koprowski H, Dietzschold B, Fu ZF, J. Virol. 73, 1661-1664, 1999.

Ye J, Rawson RB, Komuro R, Chen X, Dave UP, Prywes R, Brown MS, Goldstein JL, Mol. Cell. 6, 1355-1364, 2000. http:// dx.doi.org/10.1016/S1097-2765(00)00133-7

Zavada J, Zavadova Z, Arch. Virol. 118, 189-197, 1991.http://dx.doi. org/10.1007/BF01314029 